\title{
Application of InSAR and gravimetric surveys for developing construction codes in zones of land subsidence induced by groundwater extraction: case study of Aguascalientes, Mexico
}

\author{
J. Pacheco-Martínez ${ }^{1, a}$, S. Wdowinski ${ }^{2}$, E. Cabral-Cano ${ }^{3}$, M. Hernández-Marín ${ }^{4}$, J. A. Ortiz-Lozano ${ }^{1}$, \\ T. Oliver-Cabrera ${ }^{2}$, D. Solano-Rojas ${ }^{2}$, and E. Havazli ${ }^{2}$ \\ ${ }^{1}$ Departamento de Construcción y Estructuras, Universidad Autónoma de Aguascalientes, Aguascalientes, \\ Mexico \\ ${ }^{2}$ Department of Marine Geosciences, University of Miami, Miami, Florida, USA \\ ${ }^{3}$ Unidad de Geomagnetismo y Exploración, Universidad Nacional Autónoma de Mexico, D.F., Mexico, USA \\ ${ }^{4}$ Departamento de Geotécnia e Hidráulica, Universidad Autónoma de Aguascalientes, Aguascalientes, Mexico \\ ${ }^{a}$ now at: Department of Marine Geosciences, University of Miami, Miami, USA
}

Correspondence to: J. Pacheco-Martínez (jesus.pacheco@edu.uaa.mx)

Published: 12 November 2015

\begin{abstract}
Interferometric Synthetic Aperture Radar (InSAR) has become a valuable tool for surface deformation monitoring, including land subsidence associated with groundwater extraction. Another useful tools for studying Earth's surface processes are geophysical methods such as Gravimetry. In this work we present the application of InSAR analysis and gravimetric surveying to generate valuable information for risk management related to land subsidence and surface faulting. Subsidence of the city of Aguascalientes, Mexico is presented as study case. Aguascalientes local governments have addressed land subsidence issues by including new requirements for new constructions projects in the State Urban Construction Code. Nevertheless, the resulting zoning proposed in the code is still subjective and not clearly defined. Our work based on gravimetric and InSAR surveys is aimed for improving the subsidence hazard zoning proposed in the State Urban Code in a more comprehensive way. The study includes a 2007-2011 ALOS InSAR time-series analysis of the Aguascalientes valley, an interpretation of the compete Bouguer gravimetric anomaly of the Aguascalientes urban area, and the application of time series and gravimetric anomaly maps for improve the subsidence hazard zoning of Aguascalientes City.
\end{abstract}

\section{Introduction}

The city of Aguascalientes (725000 inhabitants), as well as other medium-sized cities (with a total of 275000 inhabitants), is located within the Aguascalientes Valley, $430 \mathrm{~km}$ NW of Mexico City (Fig. 1). The growing population and increased agricultural and industrial activities along the valley have resulted in an intensive groundwater extraction, leading to develop land subsidence since earlies 1970's (PachecoMartínez et al., 2013).

In Aguascalientes City, surface faulting was first observed in the late of 1970's, when a group of houses developed cracks and fissures in walls and floors. Because all damaged properties were aligned along a linear feature, several studies concluded that the damage was caused by an active geological fault (Aranda-Gómez, 1989; Lermo et al., 1996).

From the discovery of this fault in the late 1970's until present, new surface faults have developed along the entire valley affecting the urban areas of Cosio, San Francisco del Rincón, San Francisco de los Romos, Jesús María and Aguascalientes City, as well as other smaller towns and rural communities (Fig. 1). As a consequence of this process, several legal disputes concerning land and housing selling affected by faulting were presented in local courts. Thus, sur- 


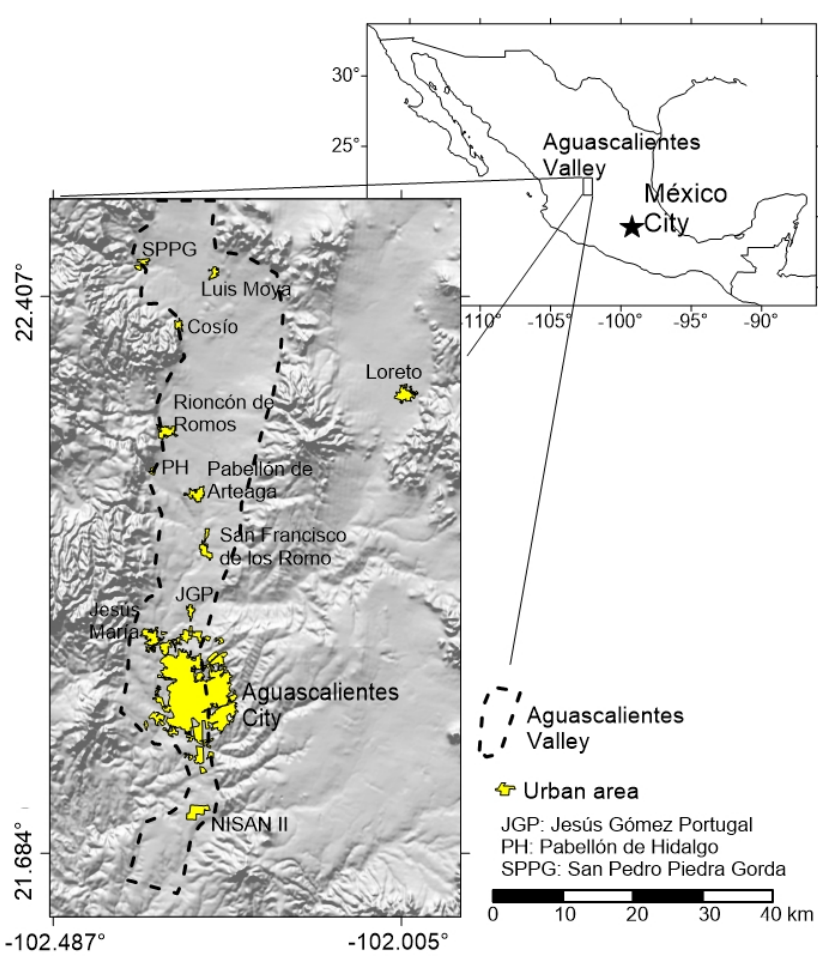

Figure 1. Location of Aguascalientes Valley. The names of minor cities and small towns are provided in the map legend.

face faulting became a major concern for the local government, specially for those bureaus responsible for providing regulatory construction codes and for bureaus dealing with planning and growing of urban infrastructure.

In this work, we present geophysical data and geodetic observations, which provide information to improve the risk zoning defined in the current construction code of Aguascalientes. These observations include ALOS InSAR timeseries the Aguascalientes valley, and gravimetric measurements in the city of Aguascalientes.

\section{Land subsidence and related faulting in Aguascalientes City}

The first reports of surface faults in the city of Aguascalientes were due to damage that a surface fault caused in several buildings in the late 1970's (Lermo et al., 1996; ArandaGómez, 1989), but there were no estimates about the subsidence magnitude at that time. However, currently the affected area by subsidence is around $942 \mathrm{~km}^{2}$ with rates reaching 10 $\mathrm{cm} \mathrm{yr}^{-1}$ as shown in Sect. 4.

Ground faulting within the city is a great concern for local population, because of the structural damage that it induces to buildings, as well as to public infrastructure (PachecoMartínez et al., 2011; Romero-Navarro et al., 2010). Table 1 shows that there are at least 208 ground faults locations, which affect over 1860 properties (SIFAGG, 2015).

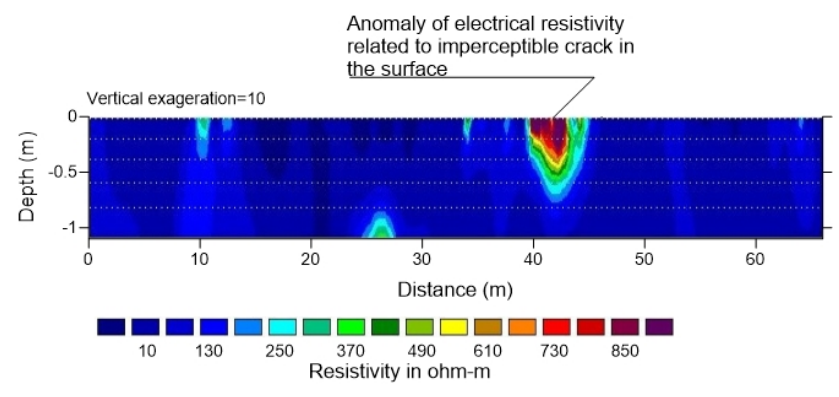

Figure 2. An example of resistivity anomaly related to a hidden or incipient surface fault surveyed in Aguascalientes City (After Pacheco-Martínez et al., 2013). Location of profile is shown in Fig. 3.

A new and bigger concern to the local government is the damage to heritage buildings in the city caused by ground faulting. In recent years, three historical buildings in the valley have been affected by surface faulting; two of them, the Cathedral of Aguascalientes and the Museum of the Insurgency are listed in the national catalogue of historic buildings.

\section{Current geotechnical practices and the Urban Code for the Aguascalientes State}

The local government responded to the ground faulting problem by implementing several actions, including the recommendations and requirements for new construction projects which have been incorporated in the Urban Code for the Aguascalientes State. The most relevant statements in the code concerning ground failure damage prevention are:

1. Certification of proficient professionals in geology or geophysics, who have to prove a background in ground faulting studies in order to be certified.

2. A requirement for municipalities to prepare and publish ground faulting maps.

3. Proposal of a zoning risk based on the shortest distance to mapped ground faults.

4. A statement that requires constructors to present geophysical or geological studies prepared by the certificated geologist or geophysics in order to obtain a construction license.

Some of the weaknesses of the Urban Code concerning the ground faulting are:

1. The code does not recognize the phenomenon of regional subsidence of the valley. The ordinance is focused solely to prevent the effects of previously mapped surface faults. 
Table 1. Ground faults length in municipalities and number of affected properties. AGS: Aguascalientes, JM: Jesús María, COS: Cosio, PAB: Pabellón, RIN: Rincón de Romos, SFCO: San Fancisco de los Romo.

\begin{tabular}{lrrrrrrr}
\hline & AGS & JM & COS & PAB & RIN & SFCO & TOTAL \\
\hline Number of mapped surface fault locations & 66 & 49 & 15 & 37 & 28 & 13 & 208 \\
Accumulated length of ground faults $(\mathrm{km})$ & 83.575 & 60.473 & 30.620 & 43.534 & 47.275 & 25.231 & 290.678 \\
Number of damaged properties & 1438 & 183 & 35 & 86 & 35 & 88 & 1865 \\
\hline
\end{tabular}

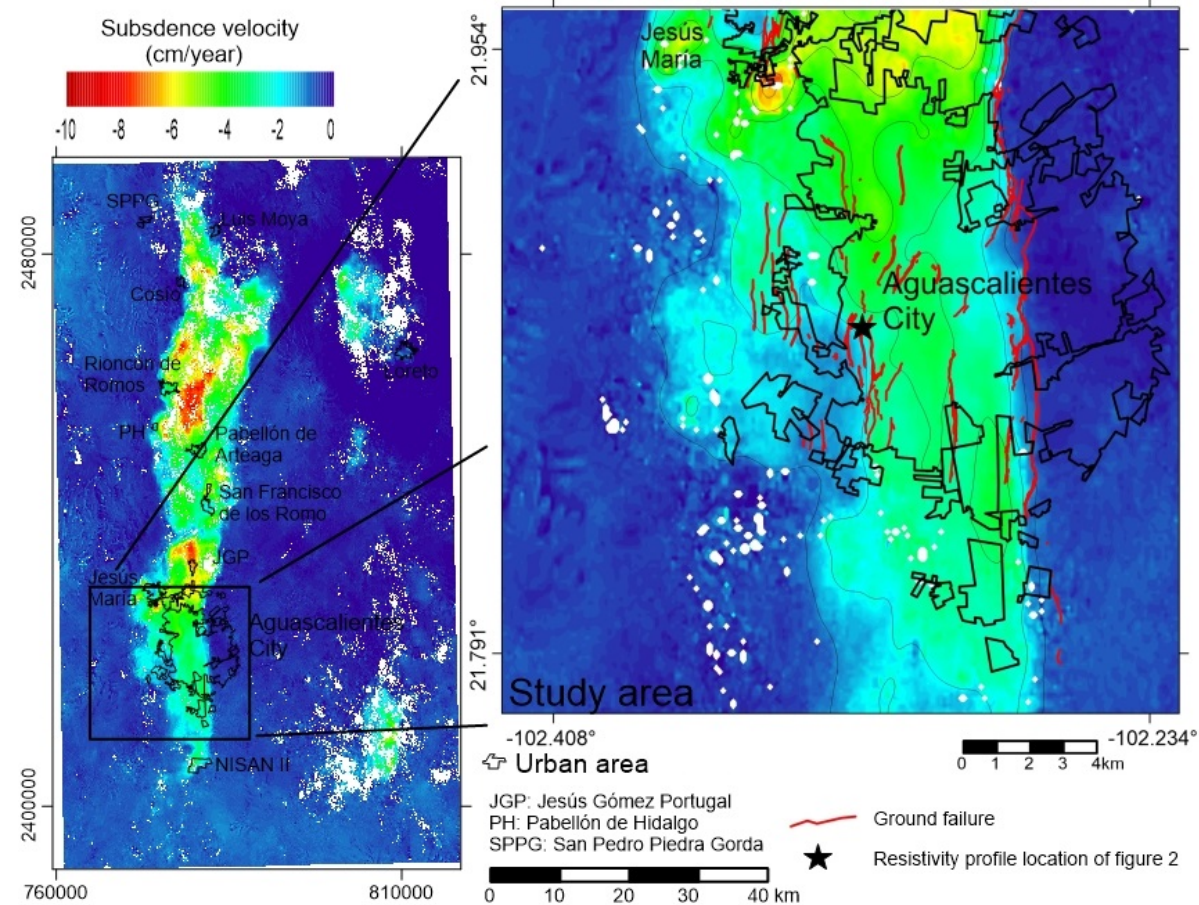

Figure 3. Subsidence velocity map of Aguascalientes Valley as determine from InSAR time series analysis of 2007-2011 ALOS data.

2. The proposed zoning in the code only points out the potential seismic risks to buildings related to the ground fault motion. The zoning does not include considerations about the hazard related to future ground fault evolution nor about the hazard associated to the differential subsidence in progress. The code recognizes three risk zones:

Zone I. High risk: terrain located within a $5 \mathrm{~m}$ wide buffer zone (or that determined by a municipality technician) along the axis of the ground failure. The code states that this zone has a high risk for urban development because the zone is under the influence of seismic activity and differential settlements caused by the motion of ground faults.

Zone II. Medium risk: terrain located within a 200-m wide buffer zone on each side from the zone I. The code states that in zone II the buildings or structures are still under the influence of seismic activity, which are originated along ground faults.
Zone III. All the terrain outside of zone I and II. The code states that the constructions in this zone are not influenced by ground faults.

3. The Urban Code does not clearly define what type of geological or geophysical study must be carried out depending the risk zone.

4. The code compels constructors to present geological and geophysical studies for any new constructions authorization, even if new constructions are outside of the subsiding area, for example at the eastern part of Aguascalientes City (see Fig. 3) where neither subsidence nor ground failure have been documented.

Regarding to the ground fault assessments, all studies that certificated geologist and geophysics develop for construction permissions focus on providing information that can lead to determine if the studied area is affected by ground faulting. In affirmative case, the studies have to include the determination of the area affected by the fault. 


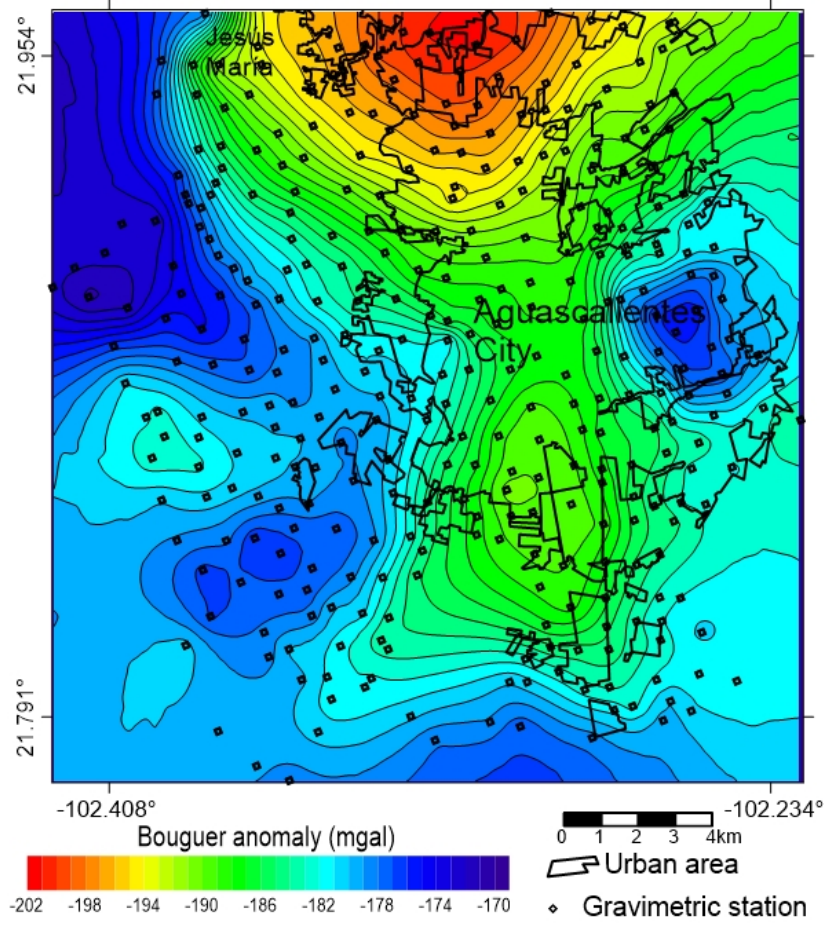

Figure 4. Complete Bouguer anomaly of the Aguascalientes city and surroundings.

The more difficult case is detecting faults at an early stage of formation. In this stage, faults may not be recognizable on the surface because either offset is very small and can be hard to detect by the erosion or by "in situ" pre-construction activities. To overcome this issue, measurements of electrical resistivity profiles of subsoil has been used with relative success to detect ground faulting in an early stage. Fractured subsoil under favorable conditions for the technique application (homogeneous stratigraphy and undisturbed soil) appears as an anomaly of high resistivity (Fig. 2).

However, under unfavourable conditions, such as a subsoil with a complex stratigraphy, deposits of anthropogenic fillings, or in zones with strong lateral water content variations, the interpretation of electrical resistivity data can be ambiguous. In such cases, geophysical measurements are complemented by trench excavation in order to directly explore where resistivity anomalies are observed. Exposed trenches help to verify the existence of incipient ground failures.

\section{The role of InSAR and gravimetric methods in subsidence studies}

InSAR techniques have been used successfully to study land subsiding areas (Ketelaar, 2009; Galloway and Burbey, 2011). The large-scale coverage of the technique and the relatively wide-spread availability of InSAR imagery have fostered its application for land subsidence studies. In some studies, InSAR was used to detect the extent of subsiding areas and subsidence rates (Chaussard et al., 2014; Galloway et al., 1998; Bell et al., 2008). Some authors have reported the use of InSAR for hazard evaluation of ground failures related to subsidence (Cabral-Cano et al., 2010, 2011).

The large-scale coverage of SAR data enabled to demonstrate that the large spatial extent of land subsidence is controlled by geologic structures and stratigraphy of the subsiding area (Amelung et al., 1999; Cigna et al., 2012). These studies concluded that groundwater level decrease is the triggering factor of the subsidence process, whereas the presence of deformable sediments determines its occurrence.

In areas where the process of subsidence began long ago, the decrease in groundwater level has taken place along the entire aquifer system, suggesting that subsidence has affected the deformable sediments in greater or lesser extent. In these circumstances, a subsidence map should show the limits of the area which have potential to develop land subsidence. The map should also show those areas in which subsidence is not likely to develop.

In the case of Aguascalientes Valley, the deformationprone aquifer system is composed of an alluvial sediments sequence with abundant silty sand and gravel contained within a regional graben; thus the limits of the subsidingprone area are also the limits of the graben. Those limits are clearly identifiable in the subsidence map of Aguascalientes Valley (Fig. 3).

The velocity map of Fig. 3 was elaborated from the processing of 34 SAR images acquired by the ALOS satellite from 2007 to 2011. Images cover two frames $(420,430)$ from the ascending track 191 . Imagery was processed with the differential InSAR technique (D-InSAR) to obtain 28 interferograms and the small baseline (SB) to generate the InSAR time-series (Rosen et al., 2000; Berardino et al., 2002; Lanari et al., 2004). We use for processing ROI_PACK software developed by NASA's Jet Propulsion Laboratory (Rosen et al., 2004). Topographic correction was applied according to Fattahi and Amelung (2013). Pixels with temporal coherence lesser than 0.7 were dismissed for elaborating the velocity map.

In Mexico, the subsurface geology of many subsiding areas consists of sequences of unconsolidated granular strata lying over a rigid bedrock, usually volcanic or carbonated rocks. Consequently, the density contrast between these units is significant, and very favorable for gravimetric analysis. Gravimetry provide in this way valuable information about the configuration of the bedrock in sedimentary basins (Pacheco-Martínez et al., 2006, 2010; Yutsis et al., 2014).

Furthermore, some studies have shown that in geological settings susceptible to develop subsidence by groundwater extraction, there is an inverse correlation between sediment thickness and the gravimetric anomaly (Jachens and Holzer, 1979; Pacheco-Martínez et al., 2006, 2010). In other words, the higher values of the gravimetric anomaly correlate with 


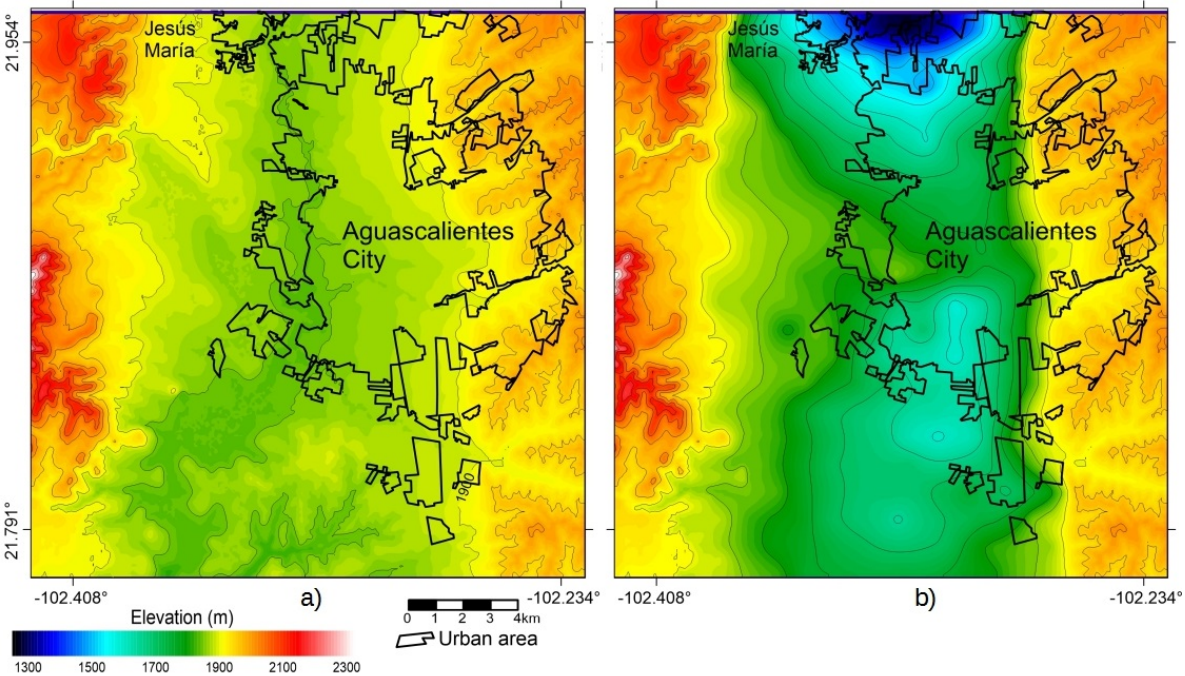

Figure 5. Surface (a) and bedrock (b) topography in the Aguascalientes City study area.

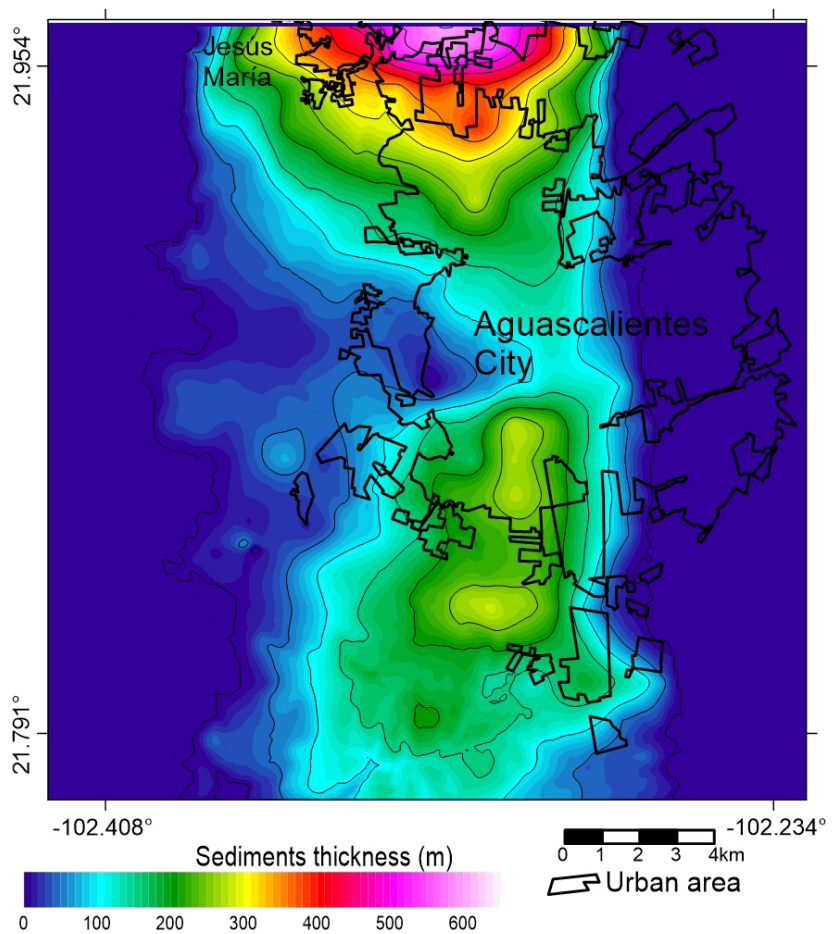

Figure 6. Map of sediments thickness in Aguascalientes City.

small sediment thicknesses. Inversely, lower anomaly values correspond to thicker sedimentary sequences.

Figure 4 shows the complete Bouguer's anomaly of Aguascalientes City subsidence area, which was elaborated from a surveying of 339 ground-based gravimetric measurements. Gravity field data were surveyed using a CG5 gravimeter from Scintrex. Standard procedures for fieldworks and data processing where followed (Telford et al.,
1990) . The gravity data were inverted according to Singh and Guptasarma (2001) using PyGMI software developed by Cole (2015) in order to determine a model of the rocky stratum (Fig. 5). The Rocky stratum model was restrained in several points in which rocky stratum depth is known through lithology logs wells and outcrops in both sides of the graben. Finally, an isopach map (Fig. 6), which is a sediment thickness variations map, was calculated from the difference in elevations of the rocky stratum and the terrain surface.

\section{Subsidence hazard zoning map elaboration}

The hazard level related to subsidence depends on the existence of deformable sediments. It depends also on the advance degree of the subsidence process, whether superficial sinking and ground failure have been observed. Hence, three hazard factors were considered in order to complete a hazard factors array, from which the hazard level was calculated according to the existence of such factors (Table 2).

The zoning map (Fig. 7) was prepared according to a spatial analysis of the hazard factors presented in Table 2. Each hazard zone and the suggested requirements for geotechnical studies needed to evaluate the existence of ground failure in the terrain of new projects are described bellow from low to high level.

Zone 4 non-existent hazard: neither subsidence nor ground failure have been detected. Furthermore deformable filling thicknesses are negligible in this zone. Standard geotechnical studies should be enough.

Zone 3 low hazard: neither subsidence nor ground failure have been detected. Nevertheless the isopach map shows thicknesses of deformable sediments which can be significant, then subsidence could develop in the future. Standard geotechnical studies plus a superficial geological study 


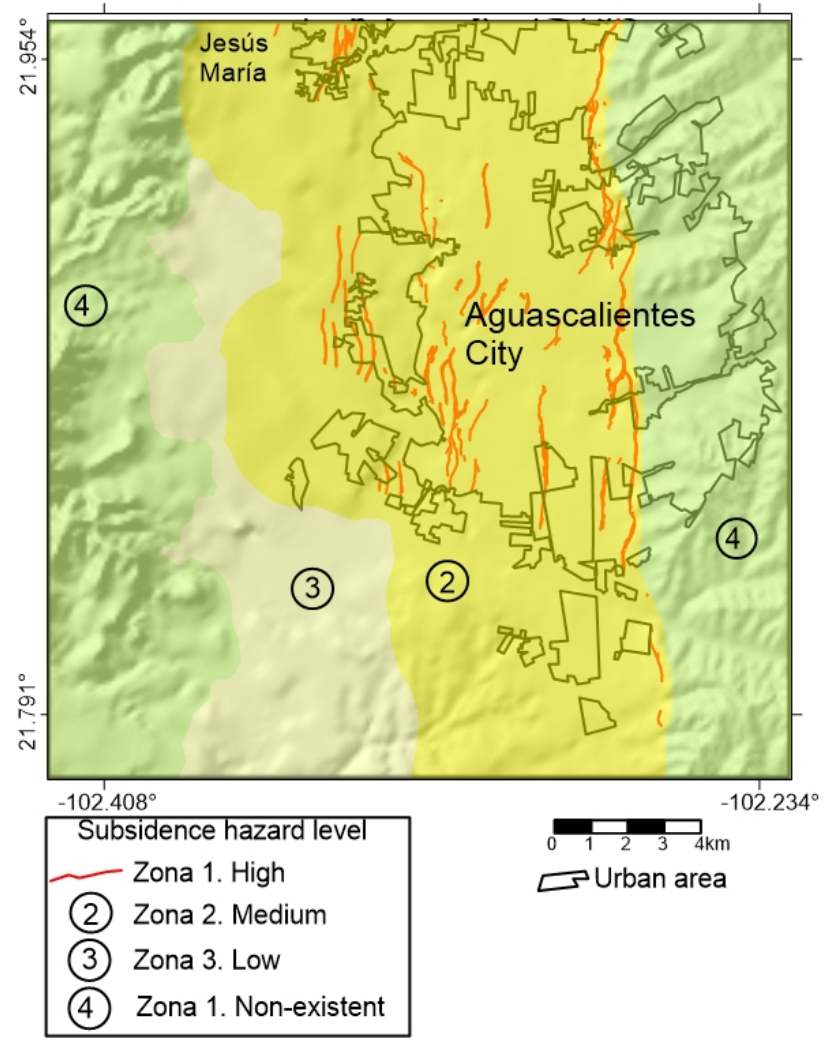

Figure 7. Subsidence hazard zoning map of Aguascalientes City.

searching for evidences of pre-subsidence cracks should be enough.

Zone 2 medium hazard: subsidence is developing, but ground failure has not been detected. Same requirements of level 3 plus a geophysical study to find out incipient ground failure.

Zone 1 high hazard: this zone corresponds to the existent ground failure traces. Same requirements of level 2 plus a detailed study to determine the trace width over which differential subsidence could cause damage on new constructions.

\section{Conclusions}

The zoning map of subsidence and surface faulting prone area is an important element in risk management of land subsidence and associated surface faults. In this vein, Gravimetric measurements and InSAR-derived velocity maps provide valuable information for its generation. The first allows determining sediment thickness prone to deform, and the second one helps determining accurately where subsidence is present.

The combination of both information sources, along with reliable subsurface geological information, allows us to determine in a comprehensible and sustainable way the subsidence hazard map for Aguascalientes. This map will allow government agencies responsible for urban growth plan-
Table 2. Hazard factor array and resulting hazard levels. H: High level, M: Medium level, L: Low level, N: non-existent level.

\begin{tabular}{lllll}
\hline & \multicolumn{4}{c}{ Hazard levels } \\
\cline { 2 - 5 } Hazard factors & $\mathrm{H}$ & $\mathrm{M}$ & $\mathrm{L}$ & $\mathrm{N}$ \\
\hline Deformable sediments existence & Yes & Yes & Yes & No \\
Detected surface sinkings & Yes & Yes & No & No \\
Ground failure precense & Yes & No & No & No \\
\hline
\end{tabular}

ning to better define the needed technical studies according to the hazard level of the zone in which new constructions are planned.

Due to the dynamic nature of the subsidence, the hazard map have to be updated with new information generated through the geotechnical studies required for construction permissions of new projects. New SAR-images acquisitions and their processing to obtain updated velocity maps will allow regular updates of the hazard map.

Acknowledgements. J. Pacheco-Martínez thanks CONACYT for financial support: "Investigación apoyada por el CONACYT". S. Wdowinski and E. Cabral-Cano acknowledge support through NASA-ROSES grant NNX12AQ08G. E. Cabral-Cano is supported by UNAM-PAPIIT projects IN104213-2, and IN109315-3. This material is partly based on data provided by the UNAVCO Facility with support from the National Science Foundation (NSF) under award EAR-1338091.

\section{References}

Amelung, F., Galloway, D. L., Bell, J. W., Zebker, H. A., and Laczniac, R. J.: Sensing the Ups and Downs of Las Vegas: InSAR Revelas Structural Control of Land Subsidence and AquiferSystem Deformation, Geology, 27, 483-486, 1999.

Aranda-Gómez, J. J.: Geología Preliminar Del Graben de Aguascalientes, Revista Mexicana de Ciencias Geológicas, 8, 22-32, 1989.

Bell, J. W., Amelung, F., Ferretti, A., Bianchi, M., and Novali, F.: Permanent Scatterer InSAR Reveals Seasonal and Long-Term Aquifer-System Response to Groundwater Pumping and Artificial Recharge, Water Resour. Res., 44, W02407, doi:10.1029/2007WR006152, 2008.

Berardino, P., Fornaro, G., Lanari, R., and Sansosti, E.: A New Algorithm for Surface Deformation Monitoring Based on Small Baseline Differential SAR Interferograms, IEEE T. Geosci. Remote, 40, 2375-2383, 2002.

Cabral-Cano, E., Osmanoglu, B., Dixon, T., Wdowinski, S., Demets, C., Cigna, F., and Díaz-Molina, O.: Subsidence and Fault Hazard Maps Using PSI and Permanent GPS Networks in Central Mexico, Proceedings of Eighth International Symposium on Land Subsidence, 255-59, IAHS Red Books, Querétaro, Mexico: IAHS Press, Publication no. 339, 2010.

Cabral-Cano, E., Díaz-Molina, O., and Delgado-Granados, H.: Subsidencia Y Sus Mapas de Peligro: Un Ejemplo En El Área Noror- 
iental de La Zona Metropolitana de La Ciudad de Mexico, Boletín de La Sociedad Geológica Mexicana, 63, 53-60, 2011.

Chaussard, E., Wdowinski, S., Cabral-Cano, E., and Amelung, F.: Land Subsidence in Central Mexico Detected by ALOS InSAR Time-Series, Remote Sens. Environ., 140, 94-106, 2014.

Cigna, F., Osmanoğlu, B., Cabral-Cano, E., Dixon, T. H., ÁvilaOlivera, J. A., Garduño-Monroy, V. H., DeMets, C., and Wdowinski, S.: Monitoring Land Subsidence and Its Induced Geological Hazard with Synthetic Aperture Radar Interferometry: A Case Study in Morelia, Mexico, Remote Sens. Urban Environ., 117, 146-161, 2012.

Cole, P.: PyGMI-Python Geophysical Modeling and Interpretation (version 2.2.6). South Africa: Council for Geosciences, Geological Survey of South Africa, available at: http://patrick-cole. github.io/pygmi/index.html, 2015.

Fattahi, H. and Amelung, F.: DEM Error Correction in InSAR Time Series, IEEE T. Geosci. Remote, 51, 4249-4259, 2013.

Galloway, D. L. and Burbey, T. J.: Review: Regional Land Subsidence Accompanying Groundwater Extraction, Hydrogeol. J., 19, 1459-1486, 2011.

Galloway, D. L., Hudnut, K. W., Ingebritsen, S. E., Phillips, S. P., Peltzer, G., Rogez, F., and Rosen, P. A.: Detection of Aquifer System Compaction and Land Subsidence Using Interferometric Synthetic Aperture Radar, Antelope Valley, Mojave Desert, California, Water Resour. Res., 34, 2573-2585, 1998.

Jachens, R. C. and Holzer, T. L.: Geophysical Investigation of Ground Failure Related to Ground Water Withdrawal-Picacho Basin, Arizona, Ground Water, 17, 574-585, 1979.

Ketelaar, V. B. H.: Satellite Radar Interferometry - Subsidence Monitoring Techniques, Springer, 2009.

Lanari, R., Mora, O., Manunta, M., Mallorqui, J. J., Berardino, P., and Sansosti, E.: A Small-Baseline Approach for Investigating Deformations on Full-Resolution Differential SAR Interferograms, IEEE T. Geosci. Remote, 42, 1377-1386, 2004.

Lermo, J., Nieto-Obregón, J., and Zermeño, M.: Faults and Fractures in the Valley of Aguascalientes. Preliminary Microzonification, Proceedings of the Eleventh World Conference on Earthquake Engineering, Acapulco Mexico, 1996.

Pacheco-Martínez, J., Arzate-Flores, J., Rojas, E., Arroyo, M., Yutsis, V., and Ochoa, G.: Delimitation of Ground Failure Zones due to Land Subsidence Using Gravity Data and Finite Element Modeling in the Querétaro Valley, Mexico, Eng. Geol., 84, 143-160, 2006

Pacheco-Martínez, J., Arzate-Flores, J. A., López-Doncel, R., Barboza-Gudiño, R., Mata-Segura, J. L., Del-Rosal-Pardo, A., and Aranda-Gómez, J. J.: Zoning Map of Ground Failure Risk due to Land Susbidence of San Luís Potosí, Mexico, Proceedings of Eighth International Symposium on Land Subsidence, 179-184, Querétaro, Mexico: IAHS Press, Publication no. 339, 2010.
Pacheco-Martínez, J., Zermeño-De-León, M. E., Ortiz-Lozano, J. A., Solís-Pinto, A., Romero-Navarro, M. A., Aguilar-Valdés, F. J., and Fuente-López, J. A.: Soil cracks related to land subsidence. The main geotechnical hazard affecting to construction in Aguascalientes City, Proceedings of the 14th Pan-American Conference on Soil Mechanics and Geotechnical Engineering, 8, 1-8, Toronto, Canada, 2011.

Pacheco-Martínez, J., Hernandez-Marín, M., Burbey, T. J., González-Cervantes, N., Ortíz-Lozano, J. A., Zermeño-De-Leon, M. E., and Solís-Pinto, A.: Land Subsidence and Ground Failure Associated to Groundwater Exploitation in the Aguascalientes Valley, Mexico, Eng. Geol., 164, 172-186, 2013.

Romero-Navarro, M. A., Pacheco-Martínez, J., Ortiz-Lozano, J. A., Zermeño-De-León, M. E., Araiza-Garaygordobil, G., and Mendoza-Otero, E.: Land Subsidence in Aguascalientes Valley, Mexico. Historical Review and Present Situation, Proceedings of Eighth International Symposium on Land Subsidence, 207-9, IAHS Red Books, Querétaro, Mexico: IAHS Press, Publication no. 339, 2010.

Rosen, P. A., Hensley, S., Joughin, I. R., Li, F. K., Madsen, S. N., Rodríguez, E., and Goldstein, R. M.: Synthetic Aperure Radar Interferometry, Proceedings of the IEEE, 88, 333-382, 2000.

Rosen, P. A., Hensley, S., and Peltzer, G.: Updated Repeated Orbit Interferometry Package Released, Eos, Transactions American Geophysical Union, 85, 47, 2004.

SIFAGG: Sistema de Información de Fallas Geológicas Y Grietas on Line: http://www.aguascalientes.gob.mx/sop/sifagg/web/ mapa.asp, Cartografía Digital Interactiva, Aguascalientes, Mexico: Secretaría de Obras Públicas del Estado de Aguascalientes, 2015.

Singh, B. and Guptasarma, D.: New Method for Fast Computation of Gravity and Magnetic Anomalies from Arbitrary Polyhedral, Geophysics, 66, 521-526, 2001.

Telford, W. M., Geldart, L. P., and Sheriff, R. E.: Applied Geophysics, New York, USA: Cambridge University Press, 1990.

Yutsis, V., Aranda-Gómez, J. J., Arzate-Flores, J. A., Bohnel, H., Pacheco Martínez, J., and López-Loera, H.: Maar Geophysics: Valle de Santiago Study, Proceedings of The 5th International MAAR Conference, 32-33, Querétaro, Mexico, 2014. 